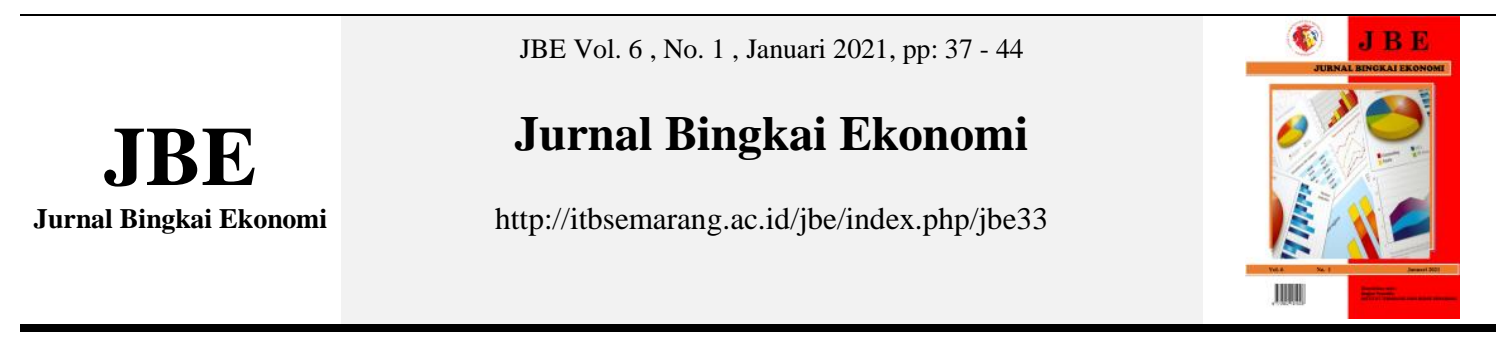

\title{
Faktor-Faktor Yang Memotivasi Mahasiswa Uniss Untuk Menjadi Wirausaha
}

Suprihono Setyawan ${ }^{1}$, Ridwan ${ }^{2}$

wawan.suprihonosetyawan@gmail.com

FEB Universitas Selamat Sri Kendal - Polikteknik Bumi Akpelni Semarang

\section{Info Artikel}

\section{Sejarah Artikel:}

Diterima : 18 Januari 2021

Disetujui : 19 Januari 2021

Dipublikasikan : 20 Januari 2021

\section{Keywords:}

Modal, Motivasi, Pemasaran,

Pelatihan, SDM.

\begin{abstract}
Abstrak
Penelitian ini bertujuan untuk menganalisis dan menguji faktor-faktor yang mempengaruhi minat mahasiswa Uniss Kendal untuk menjadi wiruusaha. Dalam penelitian ini menggunakan metode gabungan kualitatif dan kuantitatif, dengan jumlah responden sebanyak 200 mahasiswa di Uniss yang telah mengambil mata kuliah kewirausahaan, dari 200 responden tersebut yang mengisi formulir secara daring dalam menjawab kuisioner hanya 144 orang mahasiswa. Hasil penelitian menunjukkan bahwa secara parsial faktor SDM memberi pengaruh sebesar 5.3\%, modal dengan pengaruh $7.4 \%$, selanjutnya motivasi sebesar $6 \%$, pemasaran $4 \%$ dan pelatihan $5 \%$, sedangkan secara simultan faktor-faktor yang diteliti memberikan penjelasan $17.4 \%$ terhadap minat mahaiswa menjadi wirausaha, sedangkan faktor laun yang tidak diteliti sebesar $82.6 \%$.
\end{abstract}

Kata Kunci : Modal, Motivasi, Pemasaran, Pelatihan, SDM.

Abtract :

This study aims to analyze and examine the factors that influence UNISS Students' interest in becoming entrepreneurs. This studi explores the analytical approaches used in mixed methods qualitative and quantitative with the number of respondents as many as 200 students of Selamat Sri University who have taken entrepreneurship courses. The 200 respondents who filled out forms in answering questionnaires just 144 students. The results showed that partially the Human Resource Factor was influence students' interest in becoming entrepreneurs (5.3\%), then other Factors Capital was influenced 7.4\%. The result showed that Students' Motivation was influenced 6\%. While Marketing factor was influenced 4\%. And laast factor was Training influnced 5\% student in becoming entrepreneurs. Simultaneously, the factors studied provided an explanation as showed by Coeficient determination number $(17,4 \%)$, while other factors that are not studied are $82.6 \%$

Keyword : Capital, Motivation, Marketing, Training, HR

\footnotetext{
Alamat korespondensi :

Gondoarum, Jambearum, Kec. Patebon, Kabupaten Kendal, Jawa Tengah 51351

E-mail: wawan.suprihonosetyawan@gmail.com
} 


\section{PENDAHULUAN}

Dengan semakin ketatnya persaingan dalam memperebutkan satu tempat untuk mendapatkan pekerjaan, maka ketika seorang mahasiswa yang masih menyelesaikan studi terus terlena dengan asyiknya dunia kampus, secara waktu mahasiswa itu bisa dikategorikan merugi, karena didalam pola pikirnya, masa depan itu akan bisa digapai manakala sudah lulus dari bangku kuliah, sebagian mahasiswa dari kelompok ini tidak menyadari bahwa sesungguhnya masa depannya itu jauh dibelakang citacitanya. Masih ada banyak lulusan sarjana yang lama menganggur. Alasannya, karena ada jarak yang terlalu lebar di dunia pendidikan dan di dunia industri. Dari laporan BPS pada tahun 2015 disebutkan dalam tabel sebagai berikut :

Tabel 1.

Pekerja Potensial (2013 - 2015)

Pekerja Potensial (2013-2015)
\begin{tabular}{|l|c|c|c|c|c|c|}
\hline \multicolumn{1}{|c|}{$\begin{array}{c}\text { Jenis Pekerja } \\
\text { (dalam Juta) }\end{array}$} & \multicolumn{2}{|c|}{2013} & \multicolumn{2}{c|}{2014} & \multicolumn{2}{c|}{2015} \\
\cline { 2 - 7 } & Peb & Agust & Peb & Agust & Peb & Agust \\
\hline Pekerja Potensial & 123 & 120 & 125 & 121 & 128 & 122 \\
\hline Tenaga Kerja & 116 & 113 & 119 & 115 & 120 & 115 \\
\hline Belum Bekerja & 7.2 & 7.4 & 7.2 & 7.2 & 7.5 & 7.2 \\
\hline
\end{tabular}
Sumber : Badan Pusat Statistik,Jakarta 2015.

Dari tabel 1, tersebut diatas tergambar jelas khusus dalam lajur pengangguran dari bulan Februari 2013 Agustus 2016 angka tersebut fluktuatif tetapi tidak berjarak terlalu besar di tiap periodenya, ini menjadi gambaran bahwa pengangguran terbuka (diantaranya adalah sarjana) masih menjadi salah satu penyumbang pengangguran itu sendiri. Pengangguran terdidik ini disebabkan karena tujuan mereka menempuh studi lanjut setelah sekolah menengah hanyalah mencari pekerjaan, mereka tidak berani keluar dari tatanan normal untuk menjadi seorang wirausahawan. Mereka hanya mengharapkan bisa bekerja di perusahaanperusahaan ternama atau menunggu formasi dari pemerintah untuk menjadi PNS. Ini adalah fenomena besar yang harus diatasi bersama, diperlukan sinergi positif antara pemerintah, perguruan tinggi dan calon sarjana itu sendiri. Di era global saat ini dalam menghadapi persaingan ketat itu calon sarjana harus di arahkan dan didukung agar supaya bisa menciptakan lapangan pekerjaan bagi dirinya sendiri dan bagi orang lain.

Semua mahasiswa di seluruh perguruan tinggi di Indonesia harus ditumbuhkan semangat serta jiwa berwirausahanya, karena ini dipercaya bisa menjadi salah satu alternatif dalam rangka mengurangi pengangguran sarjana. Warta Ekonomi.co.id (portalberitaekonomi-senin, 26 November 2018) menyebutkan bahwa jumlah pengusaha Indonesia masih tertinggal dari Singapura Lebih lanjut dijelaskan lagi bahwa Indonesia idealnya punya 5\% dari total jumlah penduduk yang menjadi wirausahawan. Dalam persaingan bisnis di era kecanggihan teknologi ini, maka harus selalu mengandalkan knowledge dan intelectual capital.

Suryana (2014), menerangkan bahwa faktor pendorong keberhasilan kewirausahaan adalah kemampuan dan kemauan, tekad yang kuat dan kerja keras serta kesempatan dan peluang. Sedangkan faktor penghambatnya adalah suka meremehkan mutu, suka menerobos atau mengambil jalan pintas, tidak memiliki rasa kepercayaan diri, tidak disiplin dan suka mengabaikan tanggung jawab.

\section{KAJIAN TEORITIS DAN PENGEMBANGAN MODEL Wirausaha \\ Mulyadi Nitisusastro (2017)} menjelaskan bahwa berwirausaha dan menjadi pelaku usaha merupakan pilihan yang positif dan tidak terlalu sulit sepanjang tidak bertentangan dengan ketentuan perundang-undangan dan atau norma-norma lainnya.

Menurut Suryana (2014), menerangkan bahwa kewirausahaan mempelajari tentang nilai, kemampuan dan perilaku seseorang dalam berkreasi dan berinovasi.

Sedangkan menurut Widiyono \& Mukhaer (2013) mengatakan kewirausahaan, yaitu perilaku yang 
mencakup berinisiatif (initiative taking), perilaku mengorganisasi dan mereorganisasi mekanisme sosial dan ekonomi untuk mengubah sember daya atau situasi praktis, serta perilaku menerima risiko atau kegagalan.

\section{Sumber Daya Manusia}

Mulyadi Nitisusastro (2017), menjelaskan bahwa diantara sumber daya yang paling krusial yang dimiliki perusahaan adalah sumber daya manusia. Dikatakan paling krusial oleh karena sumber daya manusia merupakan satusatunya sember daya yang sekaligus mempu merencanakan, melaksanakan dan mengendalikan sumber daya yang lain.

$$
\text { Danang }
$$$$
\text { Sunyoto }
$$

menerangkan bahwa faktor yang penting dalam suatu organisasi atau perusahaan adalah manusia, disamping faktor lainnya adalah aktiva dan modal.

Sonny Sumarsono (2003), menjelaskan bahwa sumber daya manusia menggambarkan sesuatu usaha kerja maupun jasa yang benar adanya diberikan dengan tujuan menyelenggarakan proses pembuatan. Dengan kata lain sumber daya manusia ialah mutu usaha yang dicoba seorang dalam jangka waktu tertentu guna menciptakan jasa ataupun benda.

Hasibuan (2004), berpendapat SDM mempunyai makna kemampuan terpadu yang berasal dari energi pikir dan energi raga yang dipunyai oleh tiap orang.

\section{Modal}

Bambang Riyanto (2001), menerangkan bahwa modal ataupun dana sangat berarti untuk industri sebab ialah faktor utama dalam sistem keuangan industri buat melaksanakan aktivitas operasional, dimana industri mesti punya beberapa dana.

Mulyadi Nitisusastro (2013), menjelakan bahwa pembiayaan adalah penyediaan dana oleh pemerintah, pemerintah daerah, dunia usaha dan masyarakat melalui bank, koperasi dan lembaga keuangan bukan bank untuk mengembangkan dan memperkuat permodalan usaha mikro, kecil dan menengah.

\section{Motivasi}

Suryana (2014) menerangkan bahwa motivasi merupakan dorongan atau semangat untuk maju. Motivasi merupakan modal insani bagi setiap orang untuk terus hidup maju.

Melayu S.P.Hasibuan (2001), menerangkan bahwa motivasi adalah suatu perangsang keinginan (want) daya penggerak kemauan bekerja seseorang; setiap motif mempunyai tujuan tertentu yang ingin dicapai.

\section{Pemasaran}

Widiyono \& Mukhaer Pakkanna (2013), menerangkan kalau pamasaran merupakan proses dari perencanaan serta penerapan konsep yang sudah diresmikan tadinya, penentuan harga, promosi serta distribusi inspirasi, benda serta jasa buat menciptakan pergantian yang bisa memuaskan tujuan orang serta organisasi.

Agustina Shinta (2011), menjelaskan bahwa pemasaran merupakan sesuatu proses serta manajerial yang membuat orang ataupun kelompok memperoleh apa yang mereka butuhkan serta mau dengan menghasilkan, menawarkan serta mempertukarkan produk yang bernilai kepada pihak lain ataupun seluruh aktivitas yang menyangkut penyampaian produk ataupun jasa mulai dari produsen hingga konsumen.

\section{Pelatihan}

Dessler Gary (1997), menerangkan bahwa pelatihan adalah tindakan mengedukasi pegawai baru atau pegawai lama kecakapan dan kemahiran yang mereka perlukan untuk melaksanakan tugas sebagai pegawai dalam perusahaan tersebut.

$$
\text { Danang Sunyoto (2012), }
$$

menjelaskan bahwa pelatihan merupakan suatu kegiatan yang paling dapat mudah di laksanakan didalam kegiatan karyawan.

\section{Pengembangan Model}


Dari kajian teroritis tersebut diatas, maka pengembangan model penelitian dengan indikator sebagai berikut :

a. SDM ;

$\checkmark$ Manajemen bisnis sangat diperlukan untuk mendorong mahaiswa menjadi wirausaha;

$\checkmark$ Pengetahuan tentang produk sangat perlu untuk memulai menjadi wirausaha;

$\checkmark$ Mengetahui calon konsumen dan strategi pemasaran, merupakan salah satu pertimbangan untuk memulai berwirausaha;

$\checkmark$ Berkomunikasi, bekerjasama dan berorganisasi, adalah sarana pendukung dalam berwirausaha.

b. MODAL

$\checkmark$ Bantuan dari keluarga bisa menjadi salah satu sumber modal untuk berwirausaha;

$\checkmark$ Memulai beriwirausaha dengan dan dari tabungan sendiri;

$\checkmark$ Beberapa kali mendapat tawaran dari pihak lembaga keuangan sebagai tambahan modal (koperasi, bank, rekanan).

c. MOTIVASI

$\checkmark$ Mampu bekerja keras setiap saat dan menghadapi kesulitan berwirausaha;

$\checkmark$ Ingin mendapatkan uang banyak dengan berwirausaha;

$\checkmark$ Dengan menjalan kegiatan wirausaha akan mendapatkan penghasilan yang lebih besar dari pegawai;

$\checkmark$ Berusaha menciptakan lapangan pekerjaan untuk orang lain;

$\checkmark$ Dengan wirausaha maka keadaan ekonomi saya meningkat;

$\checkmark$ Berkeyakinan akan menjadi pengusaha sukses yang memiliki banyak karyawan;

$\checkmark$ Kegiatan yang saya jalankan akan mendapatkan keuntungan besar.

d. PEMASARAN $\checkmark$ Produk sangat di pengaruhi oleh cita rasa, variasi dan kemasan;

$\checkmark$ Harga produk harus terjangkau;

$\checkmark$ Lokasi mudah di jangkau dan ditemukan;

$\checkmark$ Promosi sudah meluas dan untuk semua kalangan;

$\checkmark$ Harus ada pemberian diskon.

e. PELATIHAN

$\checkmark$ Pelatihan memberikan pengetahuan yang positif;

$\checkmark$ Pelatihan membuat anda lebih mandiri;

$\checkmark$ Pelatihan membuat anda bertanggung jawab terhadap produk yang anda jual;

$\checkmark$ Pelatihan membuat anda punya komitmen terhadap jangkauan pasar produk anda;

$\checkmark$ Pelatihan meningkatkan kualitas produk anda

Selanjutnya untuk desain modelnya adalah seperti dijelaskan dalam gambar berikut ini :

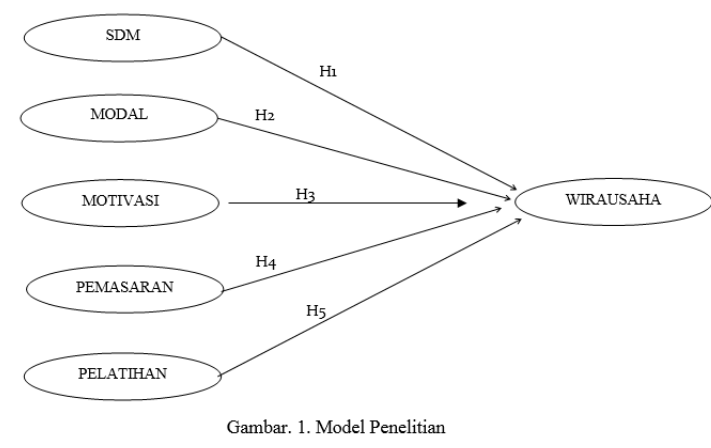

\section{Rumusan Hipotesis}

Melihat dari penjelasan model penelitian dalam tinjauan teoritis, maka penelitian ini menggunakan hipotesis sebagai berikut :

1. Hipotesis 1 : Variabel SDM berpengaruh terhadap wirausaha;

2. Hipotesis 2 : Variabel Modal berpengaruh terhadap wirausaha;

3. Hipotesis 3 : Variabel Motivasi berpengaruh terhadap wirausaha; 
4. Hipotesis 4 : Variabel Pemasaran berpengaruh terhadap wirausaha;

5. Hipotesis 5: Variabel Pelatihan berpengaruh terhadap wirausaha.

\section{METODE PENELITIAN}

Penelitian ini menggunakan metode gabungan antara kualitatif dan kuantitatif dengan maksud untuk mendapatkan jawaban yang akurat yang bisa menjelaskan masalah penelitian dengan benar, merode kuantitatif digunakan untuk menganalisis data primer yaitu data hasil angket motivasi mahasiswa dan minat wirausaha, sedangkan pendekatan kualitatif digunakan untuk menganalisis data sekunder (data pendukung) seperti hasil observasi, wawancara dan dokumentasi.

Penelitian ini melibatkan lima fakultas di Universitas Selamat Sri sebagai populasi, mahasiswa yang terlibat adalah mereka yang sudah menyelesaikan mata kuliah kewirausahaan, responden dipilih dengan menggunakan proportional random sampling (pengambilan sampel dengan berimbang dan acak). Jumlah mahasiswa yang menjadi target sebagai responden sejumlah 200 orang, dikarena kegiatan penelitian ini masih berada di masa pandemi covid-19, maka model kuisioner menggunakan bantuan google form dengan link https://bit.ly/kuisionerpenelitiandosen2020 . Dari batas waktu yang telah ditentukan, hasil kuiesoner yang masuk hanya sejumlah 144 responden. Kuisoner yang masuk inilah yang dijadikan sumber pengolahan data penelitian.

Dalam menganalisis data yang digunakan untuk menjawab rumusan masalah dalam penelitian ini adalah analisis faktor dan analisa multiple regression untuk melihat pengaruh secara sumultan antara semua variabel bebas, dan analisis regresi untuk melihat pengaruh secara individu dari variabel independen terhadap variabel depender (Minat Wirausaha).

\section{PEMBAHASAN \\ Hasil Penelitian}

Tabel 1. Data Kuisioner Faktor SDM

\begin{tabular}{|c|r|r|r|r|}
\hline Keterangan Pilihan & $\mathrm{x} 1.1$ & $\mathrm{x} 1.2$ & $\mathrm{x} 1.3$ & $\mathrm{x} 1.4$ \\
\hline SS (5) & 87 & 87 & 78 & 89 \\
\hline S (4) & 57 & 56 & 62 & 54 \\
\hline Netral (3) & 0 & 1 & 2 & 1 \\
\hline KS (2) & 0 & 0 & 2 & 0 \\
\hline TS (1) & 0 & 0 & 0 & 0 \\
\hline & 144 & 144 & 144 & 144 \\
\hline
\end{tabular}

Sumber : hasil data penelitian 2020

Tabel 2. Hasil Kuisioner Faktor Modal

\begin{tabular}{|c|r|r|r|}
\hline Keterangan Pilihan & $\times 2.1$ & $\times 2.2$ & $\times 2.3$ \\
\hline SS (5) & 32 & 43 & 8 \\
\hline S (4) & 86 & 85 & 65 \\
\hline Netral (3) & 14 & 11 & 45 \\
\hline KS (2) & 9 & 5 & 24 \\
\hline TS (1) & 3 & 0 & 2 \\
\hline & 144 & 144 & 144 \\
\hline
\end{tabular}

Sumber : hasil data penelitian 2020

Tabel 3. Hasil Kuisioner Faktor Motivasi

\begin{tabular}{|c|r|r|r|r|r|r|r|}
\hline $\begin{array}{c}\text { Keterangan } \\
\text { Pilihan }\end{array}$ & $\mathrm{x} 3.1$ & $\mathrm{x} 3.2$ & $\mathrm{x} 3.3$ & $\mathrm{x} 3.4$ & $\mathrm{x} 3.5$ & $\mathrm{x} 3.6$ & $\mathrm{x} 3.7$ \\
\hline SS (5) & 43 & 47 & 60 & 88 & 68 & 80 & 62 \\
\hline S (4) & 92 & 77 & 69 & 47 & 73 & 53 & 70 \\
\hline Netral (3) & 9 & 11 & 14 & 6 & 3 & 9 & 11 \\
\hline KS (2) & 0 & 8 & 1 & 1 & 0 & 1 & 1 \\
\hline TS (1) & 0 & 1 & 0 & 2 & 0 & 1 & 0 \\
\hline & 144 & 144 & 144 & 144 & 144 & 144 & 144 \\
\hline
\end{tabular}

Sumber : hasil data penelitian 2020

Tabel 4. Hasil Kuisioner Faktor Pemasaran

\begin{tabular}{|c|r|r|r|r|r|}
\hline $\begin{array}{c}\text { Keterangan } \\
\text { Pilihan }\end{array}$ & $\mathrm{x} 4.1$ & $\mathrm{x} 4.2$ & $\mathrm{x} 4.3$ & $\mathrm{x} 4.4$ & $\mathrm{x} 4.5$ \\
\hline SS (5) & 75 & 46 & 89 & 64 & 25 \\
\hline S (4) & 63 & 77 & 50 & 76 & 89 \\
\hline Netral (3) & 5 & 10 & 4 & 4 & 19 \\
\hline KS (2) & 1 & 11 & 1 & 0 & 11 \\
\hline TS (1) & 0 & 0 & 0 & 0 & 0 \\
\hline & 144 & 144 & 144 & 144 & 144 \\
\hline
\end{tabular}

Sumber : hasil data penelitian 2020

Tabel 5. Hasil Kuisioner Pelatihan

\begin{tabular}{|c|r|r|r|r|r|}
\hline $\begin{array}{c}\text { Keterangan } \\
\text { Pilihan }\end{array}$ & $\mathrm{x} 5.1$ & $\mathrm{x} 5.2$ & $\mathrm{x} 5.3$ & $\mathrm{x} 5.4$ & $\mathrm{x} 5.5$ \\
\hline SS (5) & 87 & 53 & 55 & 48 & 65 \\
\hline S (4) & 54 & 82 & 80 & 86 & 74 \\
\hline Netral (3) & 2 & 9 & 8 & 9 & 4 \\
\hline KS (2) & 1 & 0 & 1 & 1 & 1 \\
\hline TS (1) & 0 & 0 & 0 & 0 & 0 \\
\hline & 144 & 144 & 144 & 144 & 144 \\
\hline
\end{tabular}

Sumber : hasil data penelitian 2020 
Berdasarkan analisis dari penelitian maka didapat hasil dari $\mathrm{R}^{2}$ variabel sumber daya manusia (x1) terhadap minat wirausaha (y) sebesar 0,053 artinya bahwa pengaruh variabel independen (x1) terhadap variabel dependen (y) sebesar 5,30\%. dengan konstanta (a) $=101,901$ dan koefisien regresi $(\mathrm{b})=0,846$. Persamaan regresi antara $\mathrm{x} 1$ dengan $\mathrm{y}$ dapat diformulasikan sebagai berikut, $\hat{Y}=$ $101,901+0,846 X$.

Hasil perhitungan pengaruh faktor Modal terhadap minat wirausaha diperoleh hasil $\mathrm{R}^{2}=0,074$ artinya faktor modal memberi pengaruh senilai $7,40 \%$ kepada minat wirausaha. dengan konstanta (a) = 76,056 dan koefisien regresi (b) senilai 0,879 persamaan regresi antara $\mathrm{x} 2$ dengan y dapat formulasikan sebagai berikut, $\hat{Y}=$ $76,056+0,879 X$.

Pengaruh faktor motivasi terhadap minat wirausaha adalah sebesar $6 \%$ karena hasil dari $\mathrm{R}^{2}$ yang diperoleh sebesar 0,060. konstanta (a) $=91,446$ koefisien regresi $(b)=0,196$. Persamaan regresi antara $\mathrm{x} 3$ dengan $\mathrm{y}$ dapat diformulasikan sebagai berikut, $\hat{Y}=91,446+0,196 X$.

Pengaruh faktor pemasaran terhadap minat wirausaha adalah sebesar $4,0 \%$ karena nilai $\mathrm{R}^{2}$ yang diperoleh sebesar 0,004. konstanta (a) =83,402 dan koefisien regresi (b) senilai 0,131 . persamaan regresi antara $\mathrm{x} 4$ dengan $\mathrm{y}$ dapat diformulasi sebagai berikut, $\hat{Y}=$ $83,402+0,131 X$.

Pengaruh faktor pelatihan terhadap minat wirausaha adalah sebesar $5,0 \%$ karena nilai $\mathrm{R}^{2}$ yang diperoleh sebesar 0,005. konstanta (a) $=90,247=$ koefisien regresi $(b)=0,177$. persamaan regresi $x 5$ dengan y dapat diformulasikan, sebagai berikut $\hat{Y}=90,247+0,177 X$.

Lebih lanjut dijelaskan bahwa faktor-faktor motivasi mahasiswa secara $\mathrm{P}$ bersama-sama terhadap variabel minat wirausaha dilakukan analisis multiple regression (regresi ganda). Dana didapat dari nilai perhitungan menunjukkan bahwa pengaruh faktor motivasi mahasiswa terhadap minat wirausaha adalah sebesar $17,40 \%$ karena nilai $\mathrm{R}^{2}$ yang diperoleh adalah sebesar 0,174. Sisanya sebesar $82,60 \%$ adalah pengaruh faktor lain yang tidak diteliti.

Persamaan regresi ganda antara variabel independen $(\mathrm{x})$ terhadap variabel dependen (y) dapat diformulasikan sebagai berikut,

$\mathrm{Y}=94,680+1,203 \mathrm{X}_{1}+1.107 \mathrm{X}_{2}+0,034 \mathrm{X}_{3}+0,119 \mathrm{X}_{4}+0,026 \mathrm{X}_{5}$

dengan faktor sumber daya manusia $\left(X_{1}\right)$, faktor modal $\left(\mathrm{X}_{2}\right)$, motivasi $\left(\mathrm{X}_{3}\right)$, pemasaran $\left(\mathrm{X}_{4}\right)$, dan pelatihan $\left(\mathrm{X}_{5}\right)$.

\section{Pembahasan}

Dapat dijelaskan bahwa minat mahasiswa untuk mengambil profesi sebagai wirausaha masih sangat rendah, pada umumnya mereka masih beranggapan bahwa modal menjadi faktor utama sebagai penentu keberhasilan dalam berwirausaha. Dari hasil penelitian tersebut diatas, maka dapat dijabarkan sebagai dalam tabel sebagai berikut :

\begin{tabular}{l} 
Tabel 6. \\
\begin{tabular}{|l|r|r|r|r|}
\hline \multicolumn{1}{|c|}{ Pengaruh secara parsial minat wirusaha dikalangan mahasiswa } \\
\hline Faktor & $\begin{array}{c}\text { Adjusted } \\
\mathrm{R}^{2}\end{array}$ & $\begin{array}{c}\text { konstanta } \\
\text { (a) }\end{array}$ & $\begin{array}{c}\text { koefisien } \\
\text { regresi }(\mathrm{b})\end{array}$ & persamaan regresi \\
\hline SDM (x1) & $5,3 \%$ & 101,901 & 0,846 & $\mathrm{Y}=101,901+0,846 \mathrm{X}$ \\
\hline Modal $(\mathrm{x} 2)$ & $7,4 \%$ & 76,056 & 0,879 & $\mathrm{Y}=76,056+0,879 \mathrm{X}$ \\
\hline Motivasi $(\mathrm{x} 3)$ & $6,0 \%$ & 91,446 & 0,196 & $\mathrm{Y}=91,446+0,196 \mathrm{X}$ \\
\hline Pemasaran $(\mathrm{x} 4)$ & $4,0 \%$ & 83,402 & 0,131 & $\mathrm{Y}=83,402+0,131 \mathrm{X}$ \\
\hline Pelatihan $(\mathrm{x} 5)$ & $5,0 \%$ & 90,247 & 0,177 & $\mathrm{Y}=90,247+0,177 \mathrm{X}$ \\
\hline
\end{tabular} \\
\hline
\end{tabular}

Dalam tabel 6. dapat dijelaskan bahwa secara parsial, faktor yang paling berpengaruh terhadap minat mahasiswa dalam berwirausaha adalah faktor modal, dengan sumbangan sebesar 7,4 \% hal ini menunjukkan bahwa untuk menjadi seorang wirausahawan maka modal menjadi titik awal dalam memulai kegiatan berwirausaha

$$
\text { Tabel } 7 .
$$

\begin{tabular}{|c|c|}
\hline Faktor yang mempengaruhi & Adjusted $\mathrm{R}^{2}$ \\
\hline $\begin{array}{l}\text { SDM (x1), Modal (x2), Motivasi (x3), } \\
\text { Pemasaran (x4), Pelatihan (x5) }\end{array}$ & $17,40 \%$ \\
\hline Faktor lain yang tidak diteliti & $82,60 \%$ \\
\hline
\end{tabular}




\section{KESIMPULAN DAN SARAN Kesimpulan}

Penjelasan di dalam tahapan hasil penelitian yang sudah dijelaskan diatas, dapat disimpulkan sebagai berikut :

1. Faktor SDM dengan indikator "Berkomunikasi, bekerjasama dan berorganisasi, adalah sarana pendukung dalam berwirausaha", berpengaruh secara signifikan dan posiitf terhadap niatan untuk berwirausaha bagi mahasiswa;

2. Faktor Modal dengan indikator "Memulai beriwirausaha dengan dan dari tabungan sendiri", berpengaruh secara signifikan dan posiitf terhadap niatan untuk berwirausaha bagi mahasiswa;

3. Faktor Motivasi dengan indikator "Berusaha menciptakan lapangan pekerjaan untuk orang lain", berpengaruh secara secara signifikan dan posiitf terhadap niatan untuk berwirausaha bagi mahasiswa;

4. Faktor Pemasaran dengan indikator "Lokasi mudah di jangkau dan ditemukan", berpengaruh secara secara signifikan dan posiitf terhadap niatan untuk berwirausaha bagi mahasiswa;

5. Faktot Penelitian dengan indikator "Pelatihan memberikan pengetahuan yang positif", berpengaruh secara secara signifikan dan posiitf terhadap niatan untuk berwirausaha bagi mahasiswa.

6. Dari lima faktor tersebut, Faktor Modal mempunyai pengaruh yang besar meskipun tidak dominan dari faktor-faktor lain yang menyebabkan minat berwirausaha dikalangan mahasiswa Uniss.

\section{Keterbatasan dan Saran}

Penelitian ini di lakukan di saat masih pandemi covid-19, sehingga responden yang menjadi target tidak semuanya bisa mengirim balik kuisioner daring tersebut, keterjangkauan jaringan internet menjadi pemicu kurang lancarnya pengisian kuisioner secara daring, oleh sebab itu disarankan untuk penelitian yang akan datang apabila masih menggunakan model daring, maka harus mempertimbangkan ketersediaan jaringan internet, tetapi jika pandemi sudah berakhir maka lebih baik dilakukan secara tatap muka langsung dengan mahasiswa yang pada saat penelitian dilakukan masih menempuh mata kuliah kewirausahaan.

\section{Implikasi}

Ada 2 (dua) implikasi dalam peneliitan ini, adalah bagi pembuat regulasi, harus segera membuat roadmap bagi industri kreatif dan memberikan stimulus sehingga para pelaku industri kreatif ini bisa segera mandiri. Sedangkan impliasi bagi para pelaku industri kreatif, dengan roadmap yang jelas dari pemerintah, maka akan membantu mereka dalam pengembangan industri kreatif mereka, dan bisa menyejahterakan diri sendiri, keluarga, lingkungan sekitar dan selanjutnya akan mampu mengankat nama daerah.

\section{DAFTAR PUSTAKA}

Agustina Shinta, 2011.Manajemen Pemasaran.Unuversitas Brawijaya Press (UB Press), Malang

Alma,Buchari,2000.Kewirausahaan.Alfabe ta, Bandung

Bambang Riyanto. 2001. Dasar-dasar Pembelanjaan Perusahaan. BPFE, Yogyakarta

Melayu S.P.Hasibuan. 2003. Organisasi dan Motivasi Dasar Peningkatan Produktivitas. Bumi Aksara, Jakarta

Hendro.2011. Dasar-dasar Kewirausahaan. Penerbit Erlangga, Jakarta

Melayu S.P.Hasibuan, 2001, Manajemen Sumber Daya Manusia, Edisi Revisi. Penerbit PT.Bumi Aksara:Jakarta

Rahmawati SN. Membangun Budaya Wirausaha Melalui Peran Ibu Untuk 
Meningkatkan Nilai Tambah Ekonomi Keluarga (Studi Kasus Pada Siswa Smk Negeri 5, Jln Dr Cipto Nomor 121 Semarang). $J$ Ris Ekon Manaj. 2018;1(1):79-88. doi:10.31002/rn.v1i1.563

Suharti L, Sirine H. Faktor-Faktor yang Berpengaruh Terhadap Niat Kewirausahaan (Entrepreneurial Intention). $J$ Manaj dan Kewirausahaan. Published online 2012. doi:10.9744/jmk.13.2.124-134

Sonny Sumarsono,2003. Ekonomi Manajemen Sumber Daya Manusia dan
Ketenagakerjaan. Graha Ilmu, Yogyakarta

Supeni RE, Efendi M. Minat Mahasiswa Dalam Berwirausaha Pada Perguruan Tinggi Swasta Di Kabupaten Jember. Pros Semin Nas dan Call Pap Ekon dan Bisnis. 2017;2017:449-463.

Suryana,M.Si, Dr.2013. Kewirausahaan, Kiat dan Proses Menuju Sukses. Edisi 4. Salemba Empat, Bandung

Thomas W. Zimmerer, Norman M. Scarborough,2002, Essentials Of Entrepreneurship And Small Business Management, New Jersey : PrenticeHal 